Danilo Nikolic

Nada Marstijepovic

Sead Cvrk

Radmila Gagic

Ivan Filipovic

http://dx.doi.org/10.21278/brod67406

\title{
EVALUATION OF POLLUTANT EMISSIONS FROM TWO-STROKE MARINE DIESEL ENGINE FUELED WITH BIODIESEL PRODUCED FROM VARIOUS WASTE OILS AND DIESEL BLENDS
}

UDC 621.436:.13:665.753:536.46:519.6:629.5.016.8:629.5(05)

Original scientific paper

\begin{abstract}
Summary
Shipping represents a significant source of diesel emissions, which affects global climate, air quality and human health. As a solution to this problem, biodiesel could be used as marine fuel, which could help in reducing the negative impact of shipping on environment and achieve lower carbon intensity in the sector. In Southern Europe, some oily wastes, such as wastes from olive oil production and used frying oils could be utilized for production of the second-generation biodiesel. The present research investigates the influence of the secondgeneration biodiesel on the characteristics of gaseous emissions of $\mathrm{NOx}, \mathrm{SO}_{2}$, and $\mathrm{CO}$ from marine diesel engines. The marine diesel engine that was used, installed aboard a ship, was a reversible low-speed two-stroke engine, without any after-treatment devices installed or engine control technology for reducing pollutant emission. Tests were carried out on three regimes of engine speeds, $150 \mathrm{rpm}, 180 \mathrm{rpm}$ and $210 \mathrm{rpm}$ under heavy propeller condition, while the ship was berthed in the harbor. The engine was fueled by diesel fuel and blends containing $7 \%$ and $20 \% \mathrm{v} / \mathrm{v}$ of three types of second-generation biodiesel made of olive husk oil, waste frying sunflower oil, and waste frying palm oil. A base-catalyzed transesterification was implemented for biodiesel production. According to the results, there are trends of NOx, $\mathrm{SO}_{2}$, and $\mathrm{CO}$ emission reduction when using blended fuels. Biodiesel made of olive husk oil showed better gaseous emission performances than biodiesel made from waste frying oils.
\end{abstract}

Key words: Olive husk oil; Waste frying oils; Biodiesel; Two-stroke marine diesel engine; Gaseous emission

\section{Introduction}

The shipping sector has become a key component of the world's economy. The world fleet of seagoing merchant ships comprises over 104,000 ships [1]. At the same time, on an annual average basis (2007-2012), ships account for 13\%, and 15\% of global sulfur oxide (SOx) and nitrogen oxides (NOx), respectively [2]. Shipping air pollution is regulated by 
Evaluation of pollutant emissions from two-stroke marine diesel engine fueled with biodiesel produced from various waste oils and diesel blends
Danilo Nikolic, Nada Marstijepovic Sead Cvrk, Radmila Gagic, Ivan Filipovic

IMO, through its International Convention for the Prevention of Pollution from Ships, MARPOL, and Annex VI. Annex VI to the Convention sets limits on NOx and SOx emissions from ship exhausts, prohibiting deliberate emissions of ozone-depleting substances and regulating shipboard incineration and emissions of volatile organic compounds (VOC) from tankers [3].

As a renewable energy source, biofuels have a favorable impact on the environment and can partly replace fossil fuels. The main drawbacks of biofuels include limited raw materials and high production costs. Yet, biodiesel could be an option in reducing the emission of pollutants and greenhouse gasses in the shipping sector. Nowadays, however, the practical experience with the use of biodiesel in the shipping industry is very scarce. The implementation of biodiesel as marine fuel was tested in a few research programs, where some advantages of biodiesel over fossil fuels were noted [4], including the fact that blending can be made of up to $100 \%$ of biodiesel, that there is reduction of particulate emissions, no adverse effects detected in marine engines and no bacterial formations detected in biofuel tanks during six-month storage time [4]. However, the programs also noted potential problems reflected in the fact that biodiesel acts as a solvent and tends to soften and degrade certain rubber and elastomer compounds that are often used in older engines and that it can easily remove deposits remaining after the use of diesel fuel in the system, causing the filters to clog. Still, the IMO study concludes that low blends of biodiesel of up to $20 \%$ (B20) could be used without any fuel system modifications [5]. The aforementioned studies were conducted on four-stroke medium-speed marine diesel engines.

In this present study, the influence of biodiesel (FAME) and diesel fuel blends on the characteristics of exhaust emissions from marine diesel engine is investigated. For the study, a reversible two-stroke, low-speed, cross-flow scavenging, four-cylinder marine diesel engine was used. The engine was fueled with pure diesel fuel and blends containing $7 \%$ and $20 \%$ of the three types of biodiesel. The biodiesel was produced in laboratory conditions, using olive husk oil, waste frying sunflower oil and waste frying palm oil. Base-catalyzed transesterification was implemented for biodiesel production.

\section{Experimental Procedure}

For the present study, a marine diesel engine was employed. It was a reversible twostroke, four-cylinder, marine diesel engine with cross-flow scavenging - model ALPHA 494 $\mathrm{R}$ produced by LITOSTROJ Ljubljana (Slovenia) under Burmeister license, Table 1. The engine can be regarded a low-speed one as the maximum engine speed is $320 \mathrm{rpm}$, while it produces the maximum power of $390 \mathrm{~kW}$. Given that it is an old-type marine diesel engine, there were no after-treatment devices installed, nor was there engine control technology to reduce pollutant emissions. As a matter of fact, such a situation is preferable for investigation of direct influence of biodiesel on exhaust emission from marine diesel engines. Engine was running for 8,600 hours after the last overhaul and were no any adjustments of the engine for this experiment.

The direct propulsion system of the ship comprises of the engine, propeller shaft connected to the output coupling, and a fixed-pitch propeller. Tests were conducted when the ship was berthed in harbor and during the same day - in order to have the identical atmospheric conditions. Running the engine when the ship is berthed is called a heavy propeller condition. Tests were carried out on three regimes of engine speeds, $150 \mathrm{rpm}, 180$ rpm and $210 \mathrm{rpm}$. 
Evaluation of pollutant emissions from two-stroke marine diesel engine fueled with biodiesel produced from various waste oils and diesel blends
Danilo Nikolic, Nada Marstijepovic Sead Cvrk, Radmila Gagic, Ivan Filipovic

Table 1 Marine diesel engine specifications

\begin{tabular}{|c|c|c|c|c|c|}
\hline Engine producer & Engine model & Working principle & Max power & Cyl. No. & Stroke/Bore \\
\hline Burmeister & Alpha 494-R & 2-stroke & $390 \mathrm{~kW} @ 320 \mathrm{rpm}$ & 4 & $490 \mathrm{~mm} / 290 \mathrm{~mm}$ \\
\hline
\end{tabular}

During the engine operation, power is constantly changing depending on the connected consumer. In the conditions of operation of the vessel, engine power that is transmitted to the fixed pitch-propeller depends on the number of revolutions, pitch and propeller diameter. The resistance provided by a fixed-pitch propeller is proportional to the square of the propeller speed:

$$
M=k \cdot n^{2}
$$

Effective power that is delivered to the propeller could be expressed via the torque which is transmitted from the engine crankshaft, via coupling, to the propeller shaft and propeller, where it reverses the angular velocity $\omega$. The recorded average torque and shaft speed data can be used for engine effective power estimation in accordance to the formula below [6]:

$$
P_{e}=M \cdot \omega=M \frac{\pi \cdot n}{30}[k W]
$$

where:

M - represents measured torque [kNm],

$\mathrm{n} \quad$ - represents engine-propeller rotational speed [rpm].

As for the set of engine speeds and different testing fuels, measurements of propeller shaft torque and power were conducted by means of strain gauges. This method establishes a functional connection between the elastic angular deformation of the propeller shaft and engine torque / power. Measurements of the propeller shaft torque and power were conducted by installing two pairs of strain gauges (type XY21-6/350), connected in Wheatstone bridge, onto the propeller shaft. The strain gauges were mounted at an angle of $180^{\circ}$ relative to one another. Power was delivered to strain gauge from a $9 \mathrm{~V}$ voltage source. Measuring signal from the Wheatstone bridge was delivered to the radio transmitter, allowing transfer of data to the receiver. A power source, transmitter and antenna were mounted on a ringed disc made of plastic, placed on the propeller shaft, with a view to eliminate noise. Next to the shaft, a signal receiver and a speed sensor were placed. The signal receiver and the speed sensor were connected to an electronic measuring device - Spider 8. Spider 8 was connected to a personal computer. The software for data processing was "Catman 3.0". The equipment listed was produced by Hottinger Baldwin Messtehnik (HBM).

The hourly fuel consumption was measured for each engine speed and fuel type. The volumetric method of fuel consumption measurement was employed for fuel mass flow estimation according to the following formula [6]:

$$
B=\frac{V_{p} \cdot \rho_{p}}{t}[\mathrm{~kg} / \mathrm{h}]
$$

where: B - represents fuel mass flow $[\mathrm{kg} / \mathrm{h}]$,

$V_{p} \quad$ - represents fuel volume consumed during the measurement time $\left[\mathrm{m}^{3}\right]$,

$\rho_{\mathrm{p}} \quad$ - represents fuel gravity $\left[\mathrm{kg} / \mathrm{m}^{3}\right]$,

$\mathrm{t} \quad$ - represents the time period of measurement $[\mathrm{h}]$. 
Evaluation of pollutant emissions from two-stroke marine diesel engine fueled with biodiesel produced from various waste oils and diesel blends
Danilo Nikolic, Nada Marstijepovic Sead Cvrk, Radmila Gagic, Ivan Filipovic

In the experiment, an exhaust emission analyzer by Testo (model 350-MARITIME) was used to measure $\mathrm{SO}_{2}, \mathrm{CO}$, and $\mathrm{NOx}$ concentrations in the engine exhaust. The instrument itself was located on the gallery in the engine room, about two meters above the engine. The probe was posed into an opening of the exhaust gases collector (which was designed for such experiments) above the engine. A lower part of the exhaust gasses collector from the engine exhaust to the point of probe insertion was not cooled. The schematic of the exhaust emission tests is given in Figure 1. The exhaust emission measurements were conducted for each engine's speed regime, once the engine parameters were stabilized, for the same exhaust gases flow. Each running step was held for 10 minutes until exhaust emissions were stabilized and maintained while each parameter was measured and recorded, during the last 5 min of each running step. Measurements were conducted same day, in order to have almost the same atmospheric conditions within each test.

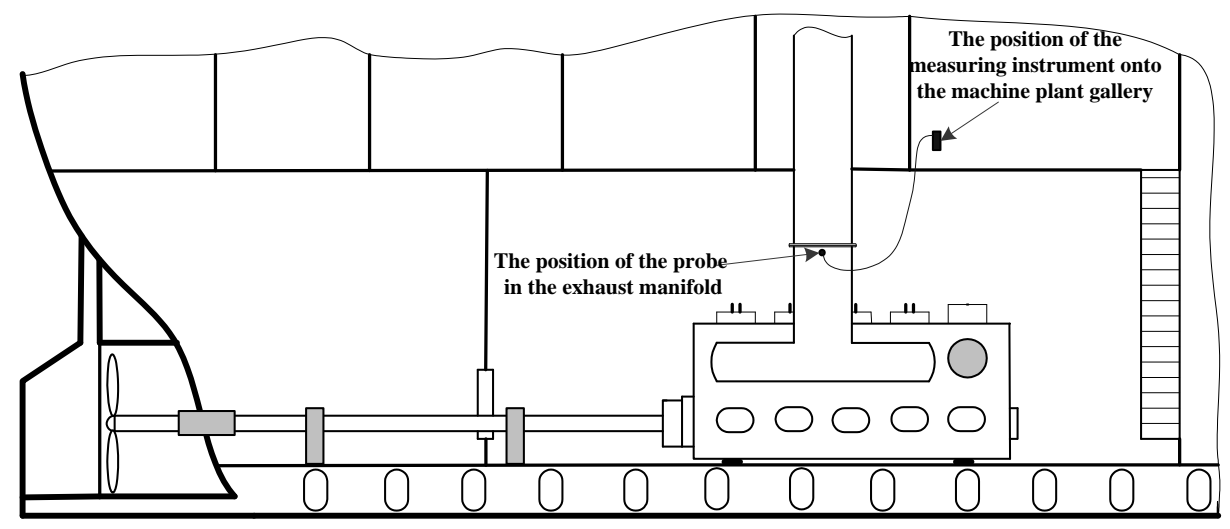

Fig. 1 The position of exhaust emission testing equipment

The engine was fueled with diesel fuel and blends containing $7 \%$ and $20 \% \mathrm{v} / \mathrm{v}$ of the three biodiesel types (FAME). Neither of the blends required adjustments of marine diesel engine [5]. The diesel fuel was a representative fuel used by the fleet of Montenegrin vessels in territorial waters with a flash point above $60^{\circ} \mathrm{C}$. The three types of biodiesel were produced in lab conditions, using waste frying sunflower oil, waste frying palm oil and olive husk oil. Waste frying oils were collected from hotels and restaurants, whereas olive husk oil was collected from the local olive oil producers in Montenegro. Base-catalyzed transesterification was used for biodiesel production. Basic test fuel properties are given in Table 2, where letter D stands for pure diesel fuel without any biodiesel addition, DS for blends of diesel fuel and biodiesel made of waste frying sunflower oil, DP for blends of diesel fuel and biodiesel made of waste frying palm oil, and DO for blends of diesel fuel and biodiesel made of olive husk oil. For blended fuels, a percentage of biodiesel in blends is added to initial letters. The tests were conducted in the summer period, so poor low-temperature properties of biodiesel were avoided.

Fuel was supplied to the engine from an outside tank. For each fuel type change, the fuel lines were cleaned and the engine was left running for at least 20 minutes to stabilize under the new conditions. Fuel samples were prepared separately and poured into separate tanks connected to the suction side of the engine fuel pump. Excess fuel was returned into the same tank. The tanks were located on the gallery in the engine room about two meters above the engine, so the fuel is delivered to the fuel pump by the force of gravity. In addition, a glass burette of known volume was attached to the tank and was used for fuel consumption measurements. 
Evaluation of pollutant emissions from two-stroke marine diesel engine fueled with biodiesel produced from various waste oils and diesel blends
Danilo Nikolic, Nada Marstijepovic Sead Cvrk, Radmila Gagic, Ivan Filipovic

Table 2 Test fuels basic properties

\begin{tabular}{|l|c|c|c|c|c|c|c|c|}
\hline Parameters & Units & $\begin{array}{c}1 \\
\mathrm{D}\end{array}$ & $\begin{array}{c}2 \\
\text { DS7\% }\end{array}$ & $\begin{array}{c}3 \\
\text { DS20\% }\end{array}$ & $\begin{array}{c}4 \\
\text { DP7\% }\end{array}$ & $\begin{array}{c}5 \\
\text { DP20\% }\end{array}$ & $\begin{array}{c}6 \\
\text { DO7\% }\end{array}$ & $\begin{array}{c}7 \\
\text { DO20\% }\end{array}$ \\
\hline Density @ $15^{\circ} \mathrm{C}$ & $\mathrm{kg} / \mathrm{m}^{3}$ & 833.4 & 837.2 & 844.4 & 836.7 & 842.9 & 837.8 & 845.9 \\
\hline Viscosity @ 40 ${ }^{\circ} \mathrm{C}$ & $\mathrm{mm}^{2} / \mathrm{s}$ & 2.92 & 2.95 & 3.12 & 3.00 & 3.19 & 3.31 & 3.46 \\
\hline Cetane number & & 51.3 & 53.5 & 54.9 & 52.5 & 54.1 & 53.8 & 55.1 \\
\hline Distillation & & & & & & & & \\
$\%(\mathrm{v} / \mathrm{v})$ recovered $@ 250^{\circ} \mathrm{C}$ & $\%(\mathrm{v} / \mathrm{v})$ & 29 & 28 & 27 & 26 & 25 & 26 & 27 \\
$\%(\mathrm{v} / \mathrm{v})$ recovered $@ 350^{\circ} \mathrm{C}$ & $\%(\mathrm{v} / \mathrm{v})$ & 91 & 91 & 89 & 92 & 92 & 91 & 89 \\
$95 \%(\mathrm{v} / \mathrm{v})$ & ${ }^{\circ} \mathrm{C}$ & 354 & 357 & 359 & 356 & 357 & 355 & 358 \\
\hline Sulfur content & $\mathrm{mg} / \mathrm{kg}$ & 8.6 & 7.8 & 6.2 & 7.9 & 6.1 & 7.8 & 6.0 \\
\hline Water content & $\mathrm{mg} / \mathrm{kg}$ & 40.94 & 79.99 & 153.42 & 71.93 & 128.23 & 56.52 & 111.44 \\
\hline Total aromatics & $\% \mathrm{~m} / \mathrm{m}$ & 22.8 & 22.3 & 20.3 & 22.5 & 20.9 & 22.4 & 20.3 \\
\hline FAME content & $\mathrm{v} / \mathrm{v}$ & 0 & 7 & 20 & 7 & 20 & 7 & 20 \\
\hline
\end{tabular}

Given that the marine diesel engine was running for 8,600 hours after the last overhaul and that there were no adjustments of the engine for this experiment, the purpose of performed measurements was to give trends of gaseous emissions in relation to different types and content of the second-generation biodiesel in the blends for the marine diesel engine in service.

\section{Results and Discussion}

\subsection{Engine Parameters}

With an increase in engine speed, torque and effective shaft power increased as well, as shown in Table 3. For the constant engine parameters, fuel consumption increased along with the increase in biodiesel share in the blends, as shown in Table 3, which is due to lower calorific value of biodiesel compared to diesel fuel.

Table 3 Dependence of engine speed on torque, effective power and fuel consumption

\begin{tabular}{|c|c|c|c|c|c|c|c|c|c|}
\hline \multirow{3}{*}{$\begin{array}{l}\text { Engine } \\
\text { speed, } \\
\text { rpm }\end{array}$} & \multirow{3}{*}{$\begin{array}{l}\text { Torque, } \\
\mathrm{Nm}\end{array}$} & \multirow{3}{*}{$\begin{array}{l}\text { Effective } \\
\text { power } \\
\text { (propeller), } \\
\mathrm{kW}\end{array}$} & \multicolumn{7}{|c|}{ Fuel consumption, $\mathrm{kg} / \mathrm{h}$} \\
\hline & & & 1 & 2 & 3 & 4 & 5 & 6 & 7 \\
\hline & & & $\mathrm{D}$ & DS7 $\%$ & DS20\% & DP7\% & DP20\% & DO7\% & DO20\% \\
\hline 150 & 4267 & 67 & 15.30 & 16.00 & 16.10 & 15.30 & 15.70 & 15.85 & 16.05 \\
\hline 180 & 5609 & 105 & 23.20 & 24.45 & 24.55 & 23.35 & 23.95 & 24.00 & 24.20 \\
\hline 210 & 7643 & 168 & 36.20 & 38.10 & 38.25 & 36.35 & 37.30 & 37.40 & 37.75 \\
\hline
\end{tabular}

\subsection{Exhaust Emission}

\subsubsection{Oxides of Nitrogen, NOx}

It can be observed from Figure 2 that the amount of NOx increased with an increase in engine speed. The reason for this is an increased combustion temperature, since the formation of NOx inside the engine cylinders is temperature-dependent [7]. 
Evaluation of pollutant emissions from two-stroke marine diesel engine fueled with biodiesel produced from various waste oils and diesel blends
Danilo Nikolic, Nada Marstijepovic Sead Cvrk, Radmila Gagic, Ivan Filipovic

The emission of NOx from a biodiesel blends fueled engine was significantly lower than the NOx emission from a diesel fueled engine, at all engine speeds. This reduction ranged from $26 \%$ (in case of diesel fuel blended with biodiesel made of waste frying palm oil) to $72 \%$ (in case of diesel fuel blended with biodiesel made of olive husk oil), and increased with an increase in biodiesel content in blends and engine speed. As regards blended fuels only, with an increase in biodiesel content from $7 \%$ to $20 \%$, there was NOx emission reduction regardless of the engine speed. Possible reasons for NOx reduction are higher cetane numbers and lower aromatic contents of the biodiesel blends compared to diesel fuel. Higher cetane numbers of the biodiesel blends compared to that of the diesel fuel are usually associated with lower NOx emissions [8,9]. An increase in cetane number reduces the size of the premixed combustion by reducing the ignition delay. This results in lower NOx formation rates given that the combustion pressure rises more slowly, giving more time for cooling through heat transfer and dilution and leading to lower localized gas temperatures [8, $10]$.

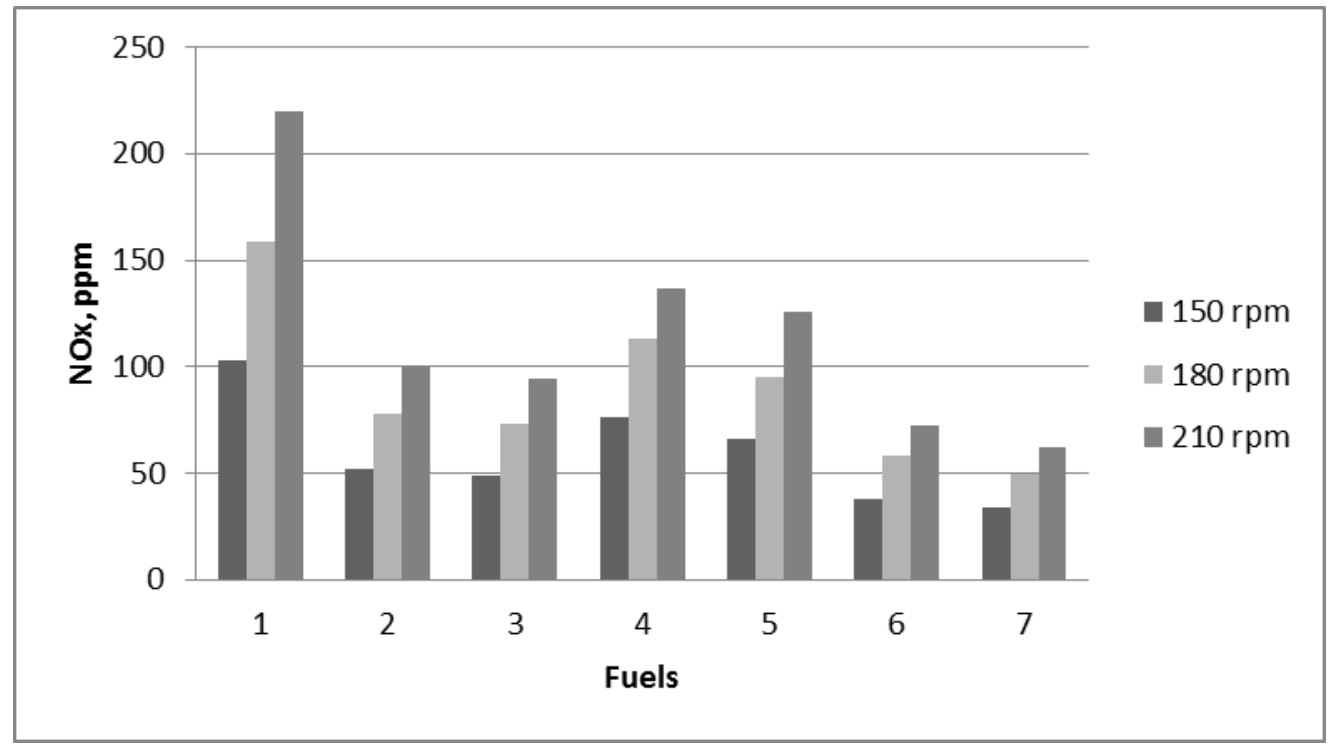

Fig. 2 Exhaust emission of NOx for different fuels and engine speeds, ppm

Furthermore, aromatic and poly-aromatic hydrocarbons are responsible for higher NOx emissions $[8,11,12,13]$. This is probably due to the higher flame temperatures associated with aromatic compounds. By reducing the aromatics, the flame temperature drops, which leads to a lower NOx production rate. As a result, the addition of biodiesel which does not contain the above classes of compounds reduces the NOx emissions from the engines. The aromatics have high carbon-hydrogen ratios and consequently fuels with lower aromatics will lead to a smaller amount of $\mathrm{CO}_{2}$ and larger amount of $\mathrm{H}_{2} \mathrm{O}$ being formed in comparison to highly aromatic fuels. Since $\mathrm{H}_{2} \mathrm{O}$ has a lower tendency to dissociate at high temperatures (compared to $\mathrm{CO}_{2}$ ), this leads to low aromatic fuels having lower concentrations of $\mathrm{O}^{*}$ radicals, which further reduces the kinetic production of NO [8]. The same trend was also reported by $[8,14,15]$. Others reported an increase of NOx emission with an increase in biodiesel proportion in blended fuels mostly due to increased oxygen content of biodiesel fuels $[16,17]$.

Comparing biodiesel feedstock type, blends containing biodiesel made of waste frying oils showed somewhat higher NOx emission than blends containing biodiesel made from olive husk oil, which could be due to their higher poly-aromatic and total aromatics content. 
Evaluation of pollutant emissions from two-stroke marine diesel engine fueled with biodiesel produced from various waste oils and diesel blends
Danilo Nikolic, Nada Marstijepovic Sead Cvrk, Radmila Gagic, Ivan Filipovic

\subsubsection{Sulfur Dioxide, $\mathrm{SO}_{2}$}

The exhaust emission of $\mathrm{SO}_{2}$ is strongly dependent on fuel sulfur content. Given that biodiesel has no sulfur content, the blending of diesel fuel with biodiesel can reduce its sulfur content and thus decrease the emission of $\mathrm{SO}_{2}$. Diesel fuel used in this experiment was standard fuel used for yachts and vessels sailing in territorial waters of Montenegro with sulfur content below 10 ppm (Table 2).

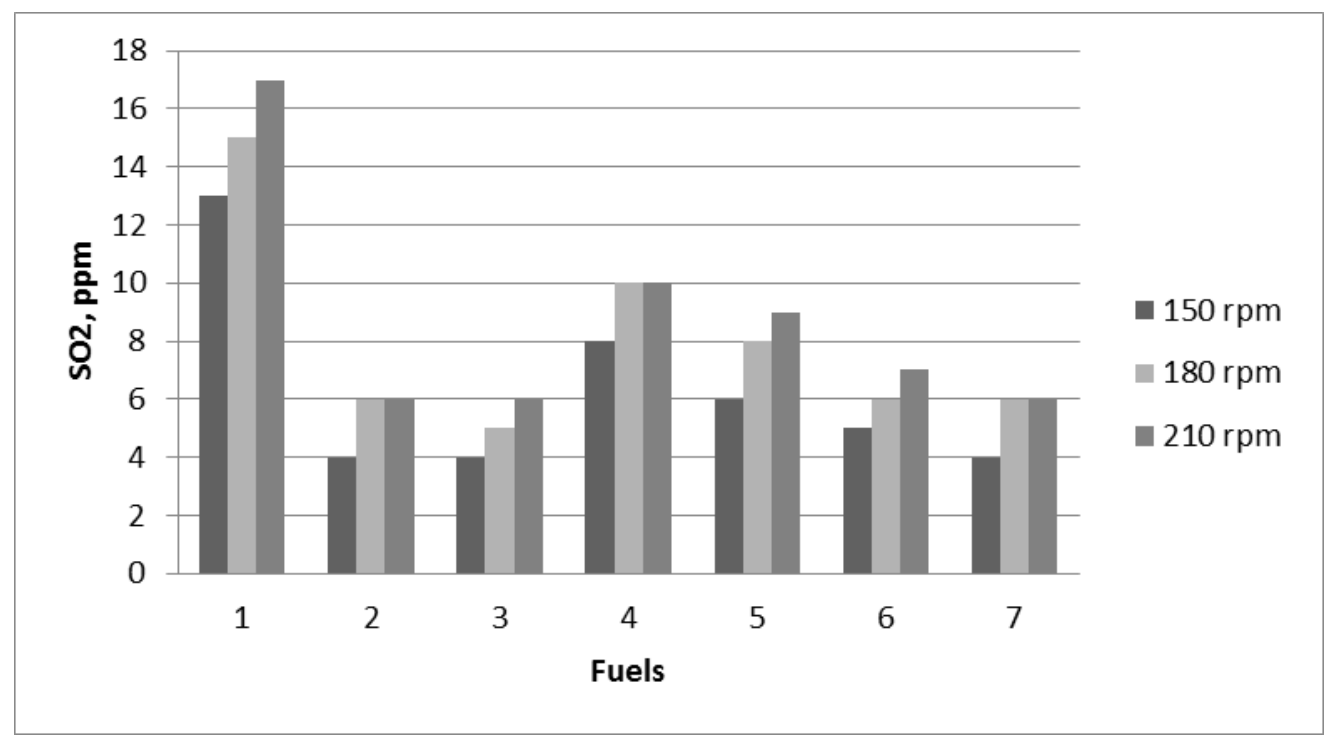

Fig. 3 Exhaust emission of $\mathrm{SO}_{2}$ for different fuels and engine speeds, ppm (to be placed in section 3.2.2)

Figure 3 reveals that $\mathrm{SO}_{2}$ emission increased with an increase in engine speed. The reason for this increase is that the more fuel is consumed the more sulfur in fuel is combusted.

Furthermore, the emission of $\mathrm{SO}_{2}$ from biodiesel-fueled engine was lower from $33 \%$ (in case of diesel fuel blended with biodiesel made of waste frying palm oil) to $70 \%$ (in case of diesel fuel blended with biodiesel made of waste frying sunflower oil) compared to dieselfueled engine.

Sulfur in diesel fuel helps lubricate the moving parts of the engine. Hence, the reduction of the fuel sulfur content in fuels decreases its lubricity [18]. Addition of as little as $2 \%$ of biodiesel into marine diesel fuel significantly improves the lubricity of the moving parts of a marine engine [19]. Therefore, adding biofuels in diesel fuel lowers $\mathrm{SO}_{2}$ emission and improves fuel lubricity, with the latter being very important for older two-stroke slow-speed engines, such as the engine used in this experiment.

\subsubsection{Carbon Monoxide, $\mathrm{CO}$}

$\mathrm{CO}$ emissions are controlled primarily by the air / fuel ratio. For fuel rich mixtures, $\mathrm{CO}$ concentration in the exhaust increases with decreasing the air / fuel ratio, as the amount of fuel increases. For fuel lean mixtures, $\mathrm{CO}$ concentration in the exhaust varies little with the air / fuel ratio. Diesel engines always operate well on the leaner side of stoichiometric [20]. 


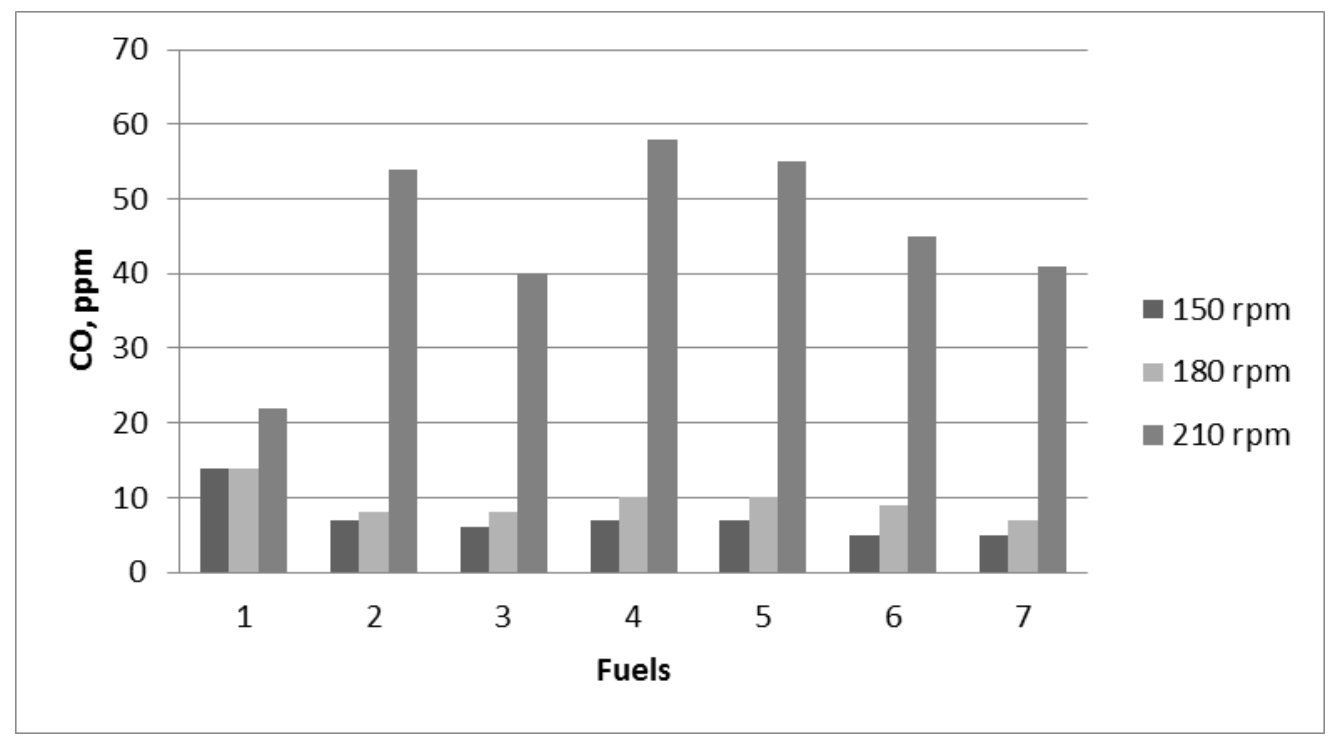

Fig. 4 Exhaust emission of CO for different fuels and engine speeds, ppm

$\mathrm{CO}$ emission slightly increased with an increase in engine speeds from $150 \mathrm{rpm}$ to 180 rpm, whereas it increased significantly with an increase in engine speeds from $180 \mathrm{rpm}$ to 210 $\mathrm{rpm}$, as shown in Figure 4. The reason for the latter is that the air / fuel ratio significantly decreases with the increase of engine speed. Similar trends were reported by [16, 21, 22].

Furthermore, emission of $\mathrm{CO}$ from biodiesel blends fueled engine was lower in the range from $28 \%$ (in case of diesel fuel blended with biodiesel made of waste frying palm oil) to $64 \%$ (in case of diesel fuel blended with biodiesel made of olive husk oil) compared to diesel-fueled engine at low and medium engine speeds. This could be possible because of the oxygenated nature of biodiesel fuel. When biodiesel blends are utilized, owing to the inbuilt oxygen in the fuel, the local air / fuel ratio during the combustion becomes leaner, which results in the reduction in the $\mathrm{CO}$ from biodiesel blends. This trend was also reported by [16, 23]. However, when applying maximum engine speed there is an evident increase in $\mathrm{CO}$ emitted when using biodiesel blends, with an increase of up to $62 \%$ compared to the $\mathrm{CO}$ emitted when using diesel fuel. At this highest engine speed, with local air / fuel ratios becoming richer, poor combustion and other biodiesel properties minimize the influence of its higher oxygen content. The same trend was also reported by [24, 25].

Comparing biodiesel feedstock type, blends containing biodiesel made of waste frying palm oil showed somewhat higher $\mathrm{CO}$ emission than other biodiesel blends, regardless of the engine speed. This could be due to its higher carbon content.

\section{Conclusion}

In the present study, an influence of the second-generation biodiesel (FAME) on the characteristics of exhaust emissions from marine diesel engine was investigated. A reversible two-stroke, low speed, cross-flow scavenging, four-cylinder marine diesel engine was used. The engine was fueled with pure diesel fuel and blends containing $7 \%$ and $20 \%$ of three types of biodiesel, made of waste frying sunflower oil, waste frying palm oil and olive husk oil. The experimental results may lead to the following conclusions:

- There is a trend of NOx emission reduction when using biodiesel blends, which could be attributed to their higher cetane number and lower aromatic content.

- There is a trend of $\mathrm{SO}_{2}$ emission reduction when using biodiesel blends, which could 
Evaluation of pollutant emissions from two-stroke marine diesel engine fueled with biodiesel produced from various waste oils and diesel blends
Danilo Nikolic, Nada Marstijepovic Sead Cvrk, Radmila Gagic, Ivan Filipovic

be attributed to their lower sulfur content.

- There is a trend of CO emission reduction when using biodiesel blends, which could be attributed to their oxygenated nature making leaner combustion.

- When blended with diesel fuel, biodiesel made of olive husk oil showed better gaseous emission performances than biodiesel made from waste frying palm oil and waste frying sunflower oil, which could be attributed to its lower poly-aromatic and total aromatics content, as well as its lower carbon content.

\section{ACKNOWLEDGMENTS}

The authors would like to thank the Montenegrin Ministry of Science for financial support under a national grant.

\section{REFERENCES}

[1] IMO International Maritime Organization, 2012. International Shipping Facts and Figures - Information Resources on Trade, Safety, Security, Environment.

[2] IMO, 2014. Third IMO GHG Study 2014 - Final Report, MEPC 67/INF.3.

[3] IMO, 2015. Note by the International Maritime Organization to the forty-third session of the Subsidiary Body for Scientific and Technological Advice (SBSTA 43) Paris, France, 1 to 4 December 2015. Agenda item 10(c) Emissions from fuel used for international aviation and maritime transport. Update on imo's work to address emissions from fuel used for international shipping.

[4] Anouk Florentinus et al., 2011. Potential of biofuels for shipping - Final Report, Ecofys 2011 by order of: European Maritime Safety Agency (EMSA)

[5] IMO, 2007. Feasibility study into the use of biofuels in the Norwegian domestic fleet, Marine Environment Protection Committee, 57th session, Agenda item 4.

[6] Tadeusz Borkowski, Lech Kasyk, Przemyslaw Kowalak, 2011. Assessment Of Ship's Engine Effective Power Fuel Consumption And Emission Using The Vessel Speed, Journal of KONES Powertrain and Transport, Vol. 18, No. 2.

[7] John B. Heywood, 1988. Internal Combustion Engine Fundamentals, McGraw Hill, ISBN 0-07-1004998.

[8] S. Kalligeros, F. Zannikos, S. Stournas, E. Lois, G. Anastopoulos, Ch. Teas, F. Sakellaropoulos, 2003. An investigation of using biodiesel/marine diesel blends on the performance of a stationary diesel engine, Biomass and Bioenergy 24, 141-149. http://dx.doi.org/10.1016/S0961-9534(02)00092-2.

[9] Monyem A, Gerpen JH, 2001. The effect of biodiesel oxidation on engine performance and emissions. Biomass and Bioenergy 20, 317-325. http://dx.doi.org/10.1016/S0961-9534(00)00095-7.

[10] Lee R, Pedley J, Hobbs Ch., 1998. Fuel quality impact on heavy duty diesel emissions - a literature review. SAE Paper No. 982649, SAE, Warrendale, PA.

[11] Takahashi S, Nikolic D, Wakimoto K, and Iida N, 2001. Effects of Aromatics Contents and 90\% Distillation Temperature of Diesel Fuels on Flame Temperature and Soot Formation, SAE Paper No. 2001-01-1940, SAE, Warrendale, PA.

[12] Spreen KB, Ulman TL, Mason RL., 1995. Effects of cetane number, aromatics and oxygenates on emissions from a 1994 heavy duty diesel engine with exhaust catalyst. SAE Paper No. 950250, SAE, Warrendale, PA.

[13] Martin B, Beckman D, Aakko P, De Giacomo N, Giavazzi F., 1997. Infuence of future fuel formulations on diesel engine emissions - a joint European study. SAE Paper No. 972966, SAE, Warrendale, PA.

[14] Dincer K., 2008. Lower emission from biodiesel combustion. Energy Source Part A 2008; 30:963-8. http://dx.doi.org/10.1080/15567030601082753. 
Evaluation of pollutant emissions from two-stroke marine diesel engine fueled with biodiesel produced from various waste oils and diesel blends
Danilo Nikolic, Nada Marstijepovic Sead Cvrk, Radmila Gagic, Ivan Filipovic

[15] Dorado MP, Ballesteros E, Arnal JM, Gomez J, Lopez FJ., 2003. Exhaust emissions form a diesel engine fuelled with transesterified waste olive oil. Fuel 2003; 82:1311-5. http://dx.doi.org/10.1016/S00162361(03)00034-6.

[16] Gumus M, Kasifoglu S., 2010. Performance and emission evaluation of a compression ignition engine using a biodiesel (apricot seed kernel oil methyl ester) and its blends with diesel fuel. Biomass Bioenergy 2010;34:134-9. http://dx.doi.org/10.1016/j.biombioe.2009.10.010.

[17] Godiganur S, Murthy CHS, Reddy RP, 2010. Performance and emission characteristics of a Kirloskar HA394 diesel engine operated on fish oil methyl esters. Renewable Energy 2010;35:355-9. http://dx.doi.org/10.1016/j.renene.2009.07.007.

[18] Muñoz, M.; Moreno, F.; Monné, C.; Morea, J.; Terradillos, J., 2011. Biodiesel improves lubricity of new low sulphur diesel fuels. Renew. Energy 2011, 36, 2918-2924. http://dx.doi.org/10.1016/j.renene.2011.04.007.

[19] National Renewable Energy Laboratory (NREL) and U.S. Department of Energy, 2009. Biodiesel Handling and Use Guide, 4th ed.; Report Number NREL/TP-540-43672; Office of Scientific and Technical Information: Oak Ridge, TN, USA,

[20] Bhardwaj, O. and Abraham, M., 2008. A comparative study of Performance and Emission Characteristics of a CRDe SUV fueled with Biodiesel blends \& Diesel fuel. SAE Technical Paper 2008-28-0075, SAE, Warrendale, PA.

[21] Usta N, Ozturk E, Can O, Conkur ES, Nas S, C, on AH, et al, 2005. Combustion of biodiesel fuel produced from hazelnut soapstock/waste sunflower oil mixture in a diesel engine. Energy Conversion and Management 2005; 46:741-55. http://dx.doi.org/10.1016/j.enconman.2004.05.001.

[22] Lertsathapornsuka V, Pairintrab R, Aryusukb K, Krisnangkura K, 2008. Microwave assisted in continuous biodiesel production from waste frying palm oil and its performance in a $100 \mathrm{~kW}$ diesel generator. Fuel Process Technology 2008; 89:1330-6. http://dx.doi.org/10.1016/j.fuproc.2008.05.024.

[23] Ramadhas AS, Muraleedharan C, Jayaraj S., 2005. Performance and emission evaluation of a diesel engine fueled with methyl esters of rubber seed oil. Renewable Energy 2005; 30:1789-800. http://dx.doi.org/10.1016/j.renene.2005.01.009.

[24] Lujan JM, Bermudez V, Tormos B, Pla B., 2009. Comparative analysis of a DI diesel engine fuelled with biodiesel blends during the European MVEG-A cycle: Performance and emissions (II). Biomass and Bioenergy 2009; 33:948-56. http://dx.doi.org/10.1016/j.biombioe.2009.02.003.

[25] Fontaras G, Karavalakis G, Kousoulidou M, Tzamkiozis T, Ntziachristos L, Bakeas E, 2009. Effects of biodiesel on passenger car fuel consumption, regulated and non-regulated pollutant emissions over legislated and real-world driving cycles. Fuel 2009; 88:1608-17. http://dx.doi.org/10.1016/j.fuel.2009.02.011.

[26] Ozsezen AN, Canakci M, Turkcan A, Sayin C, 2009. Performance and combustion characteristics of a DI diesel engine fueled with waste palm oil and canola oil methyl esters. Fuel 2009; 88:629-36. http://dx.doi.org/10.1016/j.fuel.2008.09.023.

[27] Utlu Z, Kocak MS., 2008. The effect of biodiesel fuel obtained from waste frying oil on direct injection diesel engine performance and exhaust emissions. Renewable Energy 2008; 33:1936-41. http://dx.doi.org/10.1016/j.renene.2007.10.006.

Submitted: $\quad 16.06 .2016$

Accepted: $\quad$ 14.09.2016.
Prof. dr. Danilo Nikolic, dannikol@t-com.me Nada Marstijepovic, Sead Cvrk, Radmila Gagic University of Montenegro, Maritime faculty Dobrota 36, Kotor. Montenegro

Prof.dr Ivan Filipovic

University of Sarajevo, Faculty of mechanical engineering

Vilsonovo setaliste 9, Sarajevo, Bosnia and Herzegovina 